\title{
APPLICATION OF THE TRANSMISSION ELECTRON MICROSCOPE TO THE EXAMINATION OF SPIDER EXUVIAE AND SILK*
}

\author{
By Rainer F. Foelix \\ Lehrstuhl für Zellphysiologie, Ruhr-Universität Bochum \\ D 4630 Bochum, West Germany
}

In recent years the scanning electron microscope (SEM) has been used fruitfully to study the fine structure of many arthropods, including spiders. The advantage of the SEM lies in the simple method of preparation - no embedding and sectioning has to be done - and its large depth of focus, which yields almost threedimensional views of surface structures. Drawbacks of the SEM are a limited resolution ( I 50-200 $\AA$ ) and, as well, lack of availability to most researchers. The transmission electron microscope (TEM) has a much better resolution $(<I O \AA)$ than the SEM, but requires objects of less than O.I-O.2 $\mu$ thickness to allow penetration of the electron beam.

It was found that by simply mounting parts of spider exuviae (preferably of early instars) on Formvar-coated copper grids, details of hairs and claws can be seen with the TEM. If a leg tip of an exuvia is placed on a water droplet on the Formvar membrane, it will firmly adhere to the membrane after the water has evaporated. The preparation can then be viewed immediately in the TEM. Better stability and more contrast may be achieved by shadowing the specimen at an angle of $40-50^{\circ}$ with a metal (e.g. copper). The very delicate scopula hairs (Fig. I-4) are especially well-suited for examination with the TEM, but other hairs and bristles can also be easily surveyed and classified. For instance, the open tip of chemosensitive hairs (Foelix, 1970) is convincingly demonstrated with the TEM (Fig. 5).

Spider silk, especially the extremely fine threads of cribellate silk (Fig. 6), has been studied with the TEM before (Lehmensick and Kullman, 1957; Friedrich and Langer, 1969). It should be emphasized here that shadowing with copper yields much more stable preparations. Ecribellate silk is often too thick $(\mathrm{I}-2 \mu)$ to be examined with the TEM, but accurate measurements of the diameter of various threads can be performed (Fig. 7). The substructure of the sticky

*Manuscript received hy the editor December 10, 1974. 

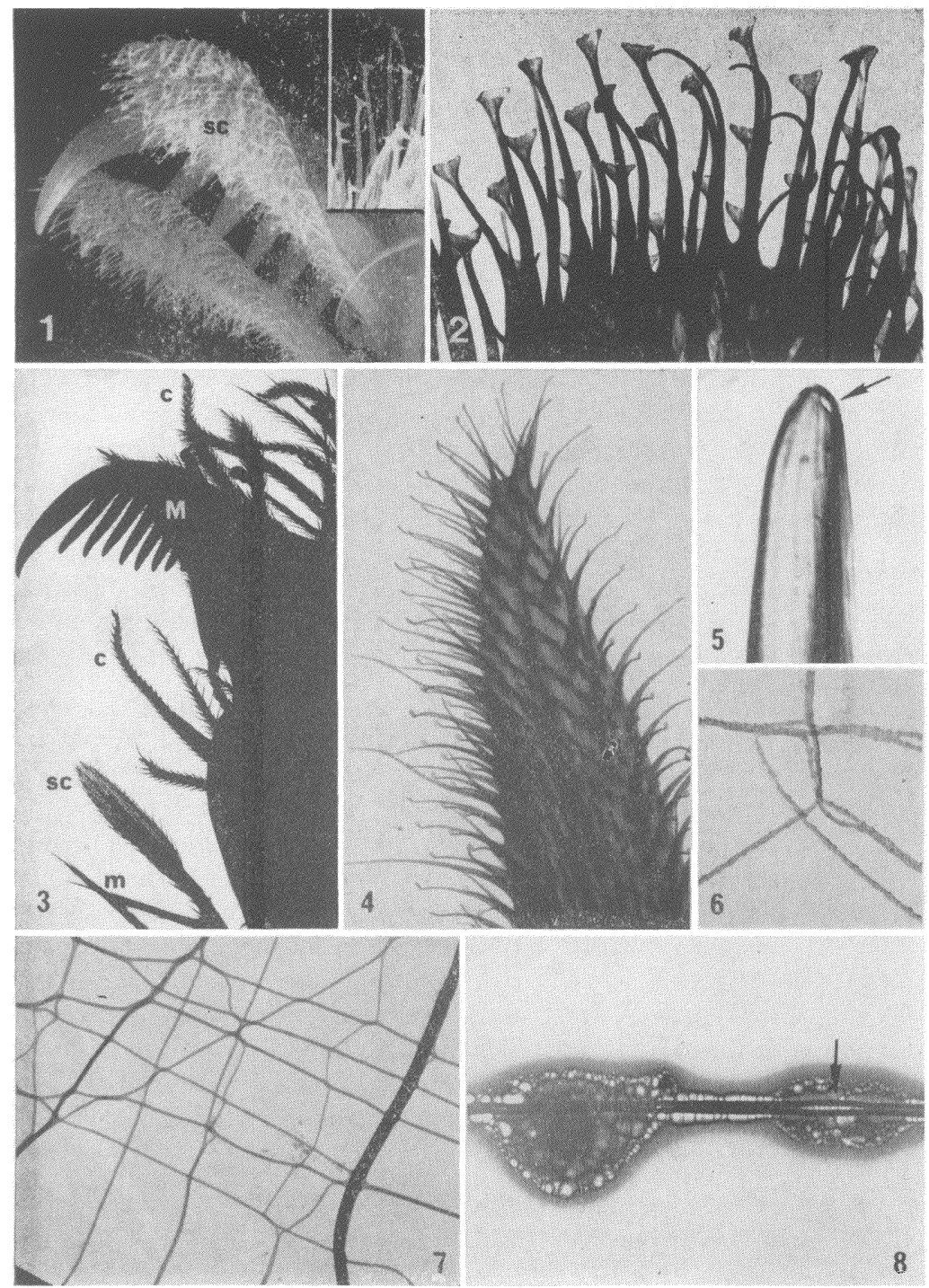
spiral of orb weavers, however, can be revealed: The glue substance partially disintegrates under the electron beam and the two axial threads become clearly visible (Fig. 8).

It is hoped that this simple technique will be usefully applied to morphological as well as taxonomical problems.

\section{References Cited}

Foelix, R. F.

1970. Chemosensitive hairs in spiders. J. Morph. 132: 313-334.

Friedrich, V. L. AND R. M. LANGer

1969. Fine structure of cribellate spider silk. Amer. Zool. 9: 91-96. LeHMENSICK, R. AND E. KULlmanN

1957. Feinbau der Fäden einiger Spinnen. Zool. Anz. Suppl. 19: 123129.

\section{Explanation of Figures on Opposite Page}

Fig. 1. Leg tip of Philodromus aureolus (nymph 2) as seen with the SEM. Scopula hairs (sc) surround the combed main claw. $1400 \times$. Inset: Scopula hairs bear fine extensions with terminal 'end-feet'. $4200 \times$. (Courtesy of Dr. W. Gnatzy). Fig. 2. The 'end-feet' of a scopula hair of Philodromus seen with the TEM. $7000 \times$. Fig. 3. Leg tip of Alopecosa accentuata (nymph 2) showing one main claw (M), chemosensitive hairs (c), mechanosensitive hairs $(\mathrm{m})$ and a scopulate hair (sc). TEM, $630 \times$. Fig. 4. Scopulate hair of Micrommata virescens. Note the small end-feet. TEM, $4200 \times$. Fig. 5. Tip of a chemosensitive hair of Philodromus. Note the terminal pore opening (arrow). TEM, $12600 \times$. Fig. 6. Cribellate silk from Amaurobius ferox. The diameter of single threads is less than $200 \AA$. Little knobs become accentuated by the metal shadowing. TEM, $28000 \times$. Fig. 7. Ecribellate silk from the silken cell of a Heliophanus. A mesh-work of fine fibers $(0.1 \mu)$ underlies several stronger fibers $(0.5 \mu)$. TEM, $2800 \times$, unshadowed. Fig. 8. Sticky spiral thread from Zygiella $x$-notata. The peripheral glue substance has precipitated around the double axial threads (arrow). TEM, $630 \times$. 

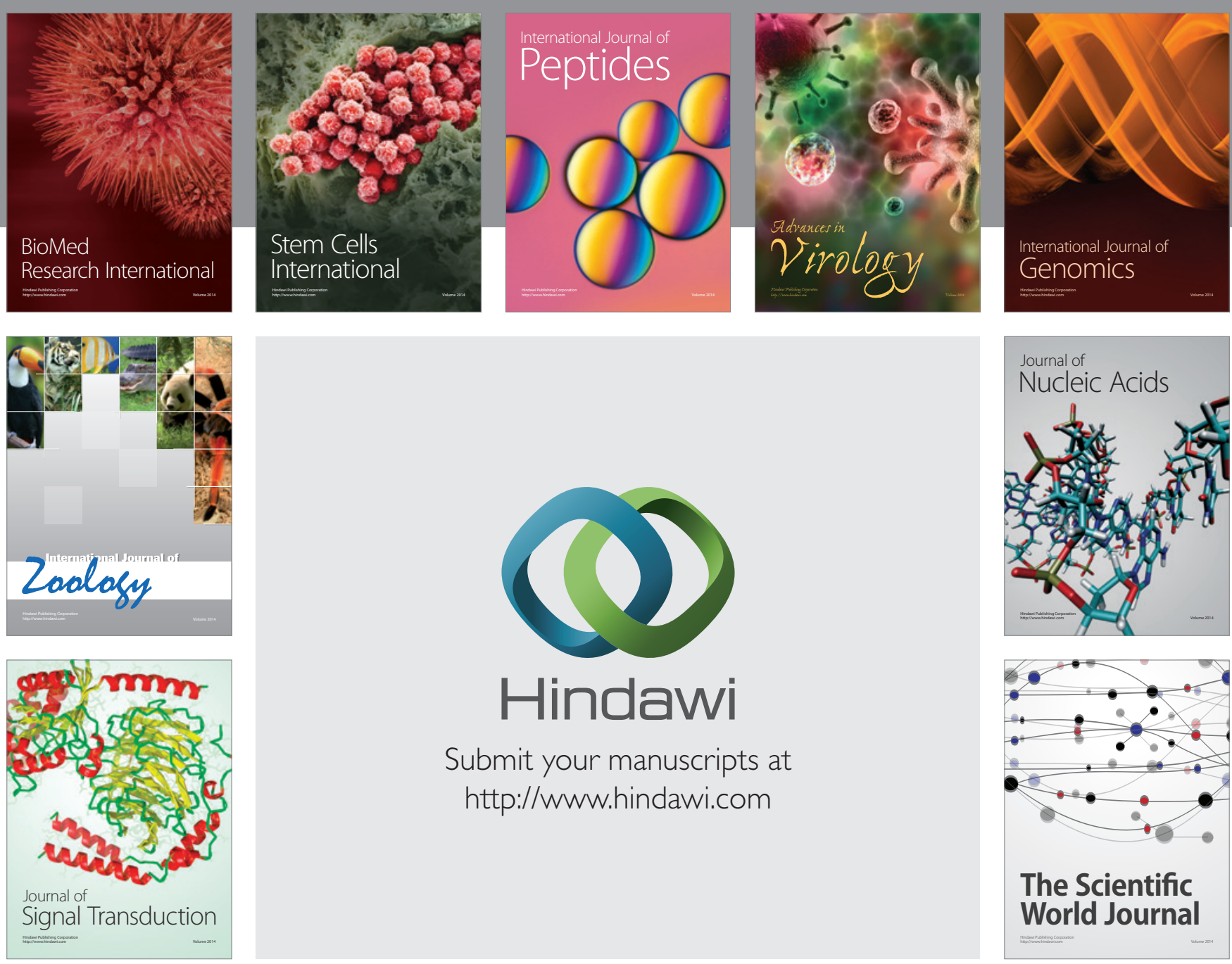

Submit your manuscripts at

http://www.hindawi.com
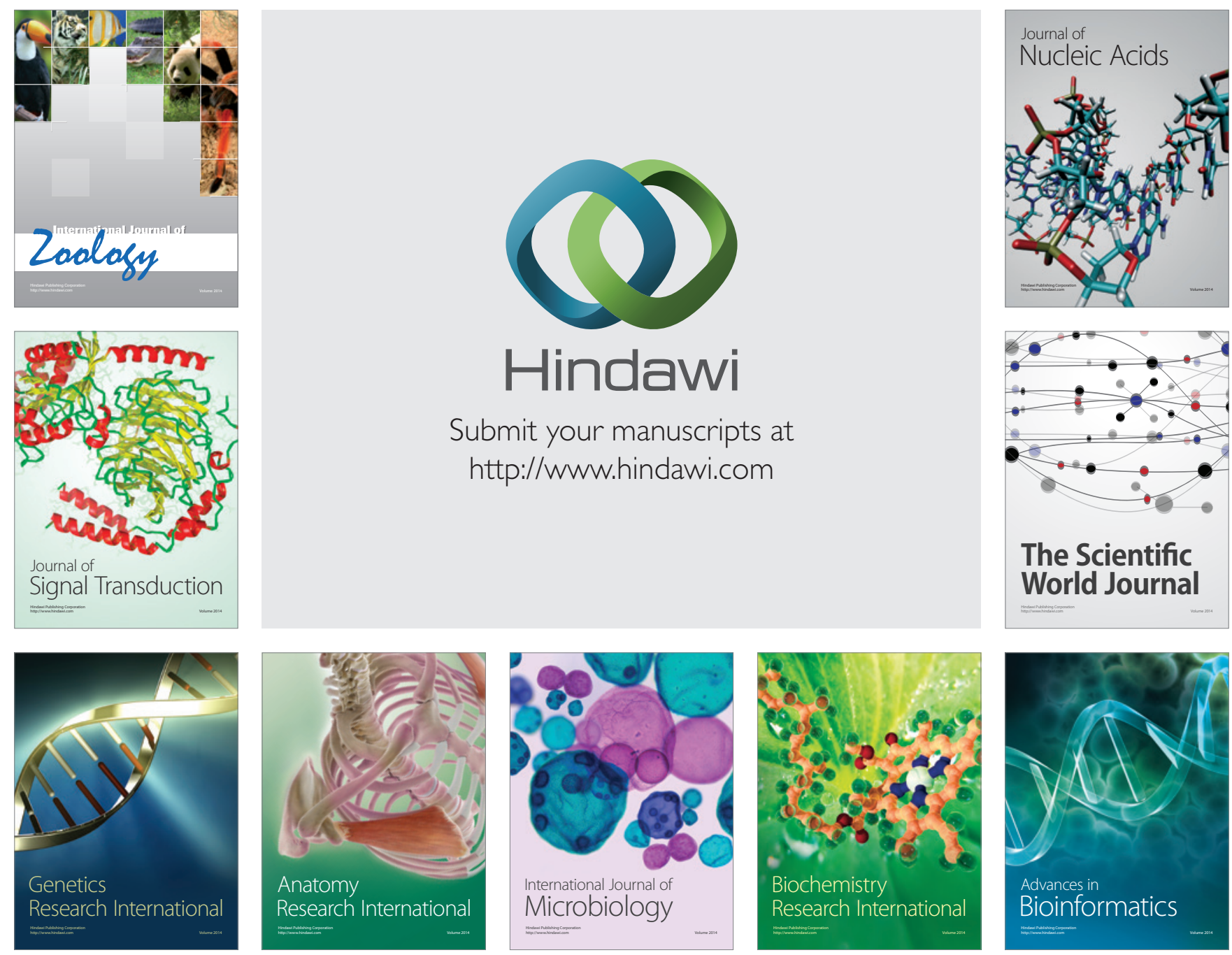

The Scientific World Journal
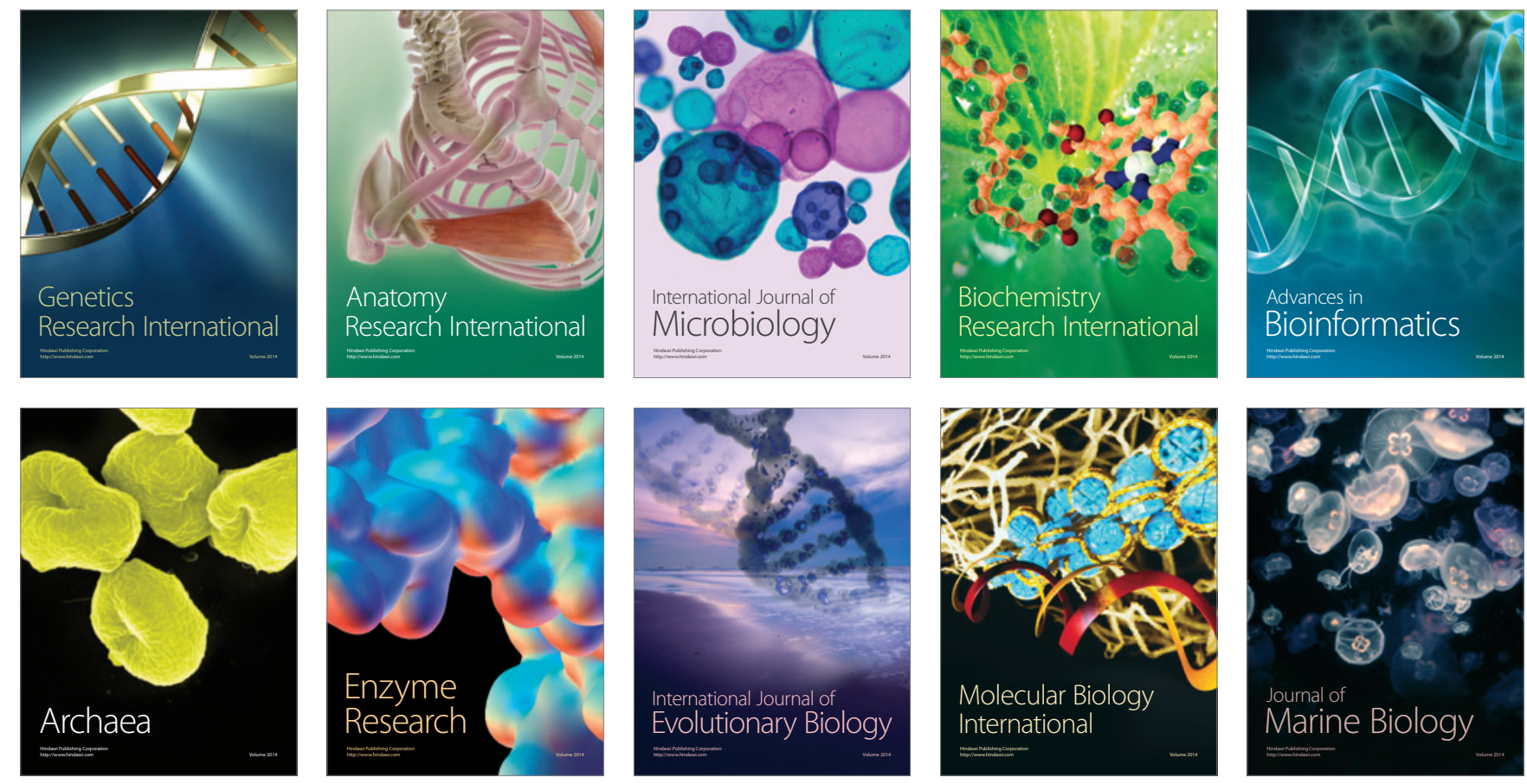